\title{
PONDOK PESANTREN DAN DERADIKALISASI ISLAM DI INDONESIA
}

\author{
Ahmad Darmadji \\ Universitas Islam Indonesia \\ Email: ahmad_darmadji@yahoo.com
}

\section{Abstract}

This article discusses the Islamic boarding schools (or pondok pesantren) in Indonesia and its role to de-radicalization of Islamic thought. Pondok pesantrens have developed within the framework of a relatively unique and have a different characters compared to similar education institutions in other countries. It's mainly caused of the nature of peace that is felt when Islam entered the country. It implies on the peaceful nature of Islam in most of the existing pondok pesantrens, including its contributions to the nation. Eventough at current circumstance some pondok pesantrens have radicalization understanding that impact on terrorism in Indonesia, it should be placed in the context of the transnational Islamic movements around the world. This article also emphasizes the importance of strengthening the role of government in an effort to de-radicalization of Islam through pondok pesantrens with the institutional strengthening of this Islamic educational institutions in the form of program to support community empowerment to break the chain of radicalization movement.

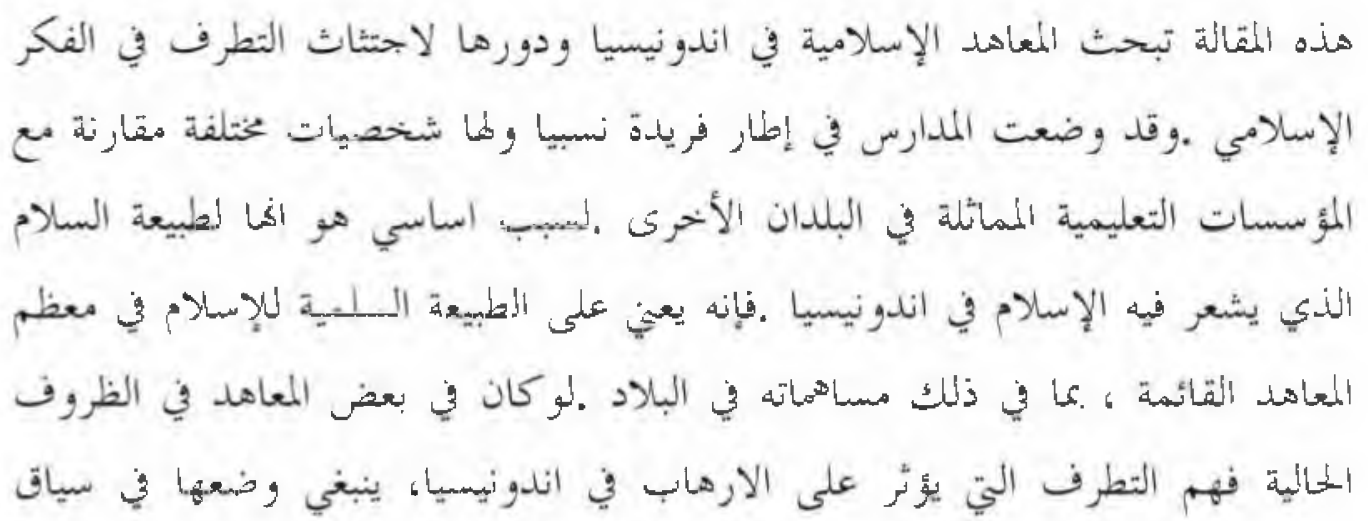




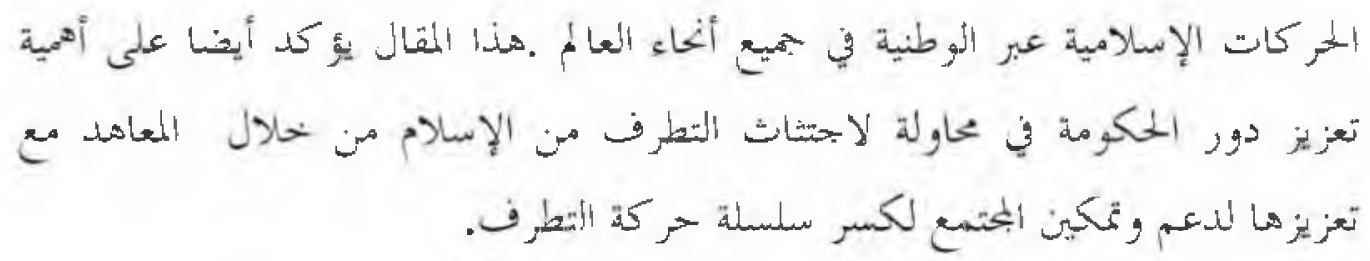

Keywords: Pondok Pesantren, Deradikalisasi, Pemberdayaan

\section{A. Pendahuluan}

Maraknya aksi radikalisme dan terorisme atas nama Islam di dunia maupun Indonesia sedikit banyak telah menempatkan umat Islam sebagai pihak yang dipersalahkan. Ajaran jihad dalam Islam seringkali dijadikan sasaran tuduhan sebagai sumber utama terjadinya kekerasan atas nama agama oleh umat Islam. Lembaga pendidikan Islam di Indonesia semisal madrasah ataupun pondok pesantren, juga tidak lepas dari tuduhan yang memojokkan tersebut. Lembaga pendidikan Islam tertua dalam sejarah Indonesia ini seringkali diasosiasikan sebagai 'markas atau sentral pemahaman Islam yang sangat fundamental' yang kemudian menjadi akar bagi gerakan radikal mengatasnamakan Islam. ${ }^{1}$

Fakta bahwa sebagian besar pelaku aksi radikalisme dan terorisme atas nama Islam di Indonesia adalah alumni pendidikan madrasah atau pondok pesantren memang tidak dapat dihindari. Namun demikian menganggap seluruh lembaga pendidikan jenis tersebut sebagai sumber ajaran radikalisme dan teoririsme jelas merupakan kesalahan mendasar mengingat karekteristik dan pola pengembangan lembaga pendidikan Islam di Indonesia yang amat beragam. Apalagi sejumlah temuan menunjukkan bahwa lembaga pendidikan Islam di Indonesia amat berbeda dibandingkan dengan lembaga pendidikan sejenis di negara lain. ${ }^{2}$

Program deradikalisasi Islam kemudian muncul ke permukaan dalam upaya untuk membendung paham radikalisme dan terorisme berlatar belakang agama di Indonesia, secara khusus ditujukan untuk ajaran Islam. Badan Nasional Penanggulangan Terorisme (BNPT) bekerjasama dengan Kementrian Agama dan pengelola pendidikan tinggi serta lembaga swadaya masyarakat lainnya di tanah air aktif mengkampanyekan gerakan deradikalisasi ini. Beragam kegiatan mulai dari seminar dan workshop hingga kegiatan

1 Republika Newsroom, "Perlu Deradikalisasi Pemahaman Islam di Ponpes", Jumat, 6 Februari 2009 dikutip dari http://koran.republika.co.id/berita/29871 diakses pada 23 Mei 2011.

2 Ibid. 
budaya pun dilakukan untuk tujuan ini. ${ }^{3}$ Respon umat Islam sendiri tentu saja beragam sesuai dengan aliran dan pemahaman keislaman yang diyakini. ${ }^{4}$

Berdasarkan latar belakang tersebut di atas, kiranya wajar jika dilakukan kajian terkait pondok pesantren dan deradikalisasi agama di Indonesia, terutama dalam rangka meningkatkan dan mengukuhkan peran lembaga pendidikan Islam dalam pembangunan karakter bangsa. Artikel ini dimaksudkan untuk menganalisa peranan yang mungkin diberikan pondok pesantren dalam rangka mengurangi pengaruh radikalisme dan terorisme di Indonesia. untuk mempermudah pembahasan, artikel ini akan menelaah perkembangan sekilas terkait pondok pesantren, radikalisme agama dalam konteks Indonesia, dan peran pondok pesantren dalam deradikalisasi agama, serta diakhiri dengan kesimpulan.

\section{B. Sekilas Perkembangan Pondok Pesantren}

Kata pondok dalam Kamus Bahasa Indonesia sebagai "madrasah dan asrama (tempat mengaji, belajar agama Islam)". ${ }^{5}$ Kata ini dapat dimaknai sebagai tempat tinggal atau tempat menginap sebagaimana kata fundûq dalam Bahasa Arab yang saat ini dimaknai hotel atau penginapan. ${ }^{6}$ Sedangkan kata pesantren sebagaimana dalam Kamus Bahasa Indonesia dimaknai sebagai "asrama tempat santri atau tempat murid-murid belajar mengaji dsb" . Pesantren secara bahasa berasal dari kata santri

3 Situs Online Universitas Gadjah Mada, "Perangi Terorisme Kedepankan Strategi Deradikalisasi”, 1 Maret 2011 dikutip dari http://www.ugm.ac.id/index.php?page=rilis\&artikel=3493 diakses pada 23 Mei 2011, Nahdhatul Ulama Online, PBNU Gelar Simposium Nasional Deradikalisasi Agama, 30 Oktober 2010 dikutip dari http://www.nu.or.id/page/id/dinamic_detil/ 1/25292/Warta/PBNU_Gelar_Simposium_Nasional_Deradikalisasi_Agama.html diakses pada 23 Mei 2011, dan Majalah Barometer Online, "Acara Deradikalisasi Dibungkus Dengan Wayang”, 4 April 2011 dikutip dari http://barometerpost.com/terorisme/85-acara-deradikalisasi-dibungkusdengan-wayang.html diakses pada 23 Mei 2011.

4 Arrahmah Online, "Proyek Deradikalisasi: BNPT "Cuci Otak" Ulama, Ormas Islam, dan Takmir Masjid," 3 Desember 2010 dikutip dari http://arrahmah.com/read/2010/12/03/10148proyek-deradikalisasi-bnpt-cuci-otak-ulama-ormas-islam-dan-takmir-masjid.html diakses pada 23 Mei 2011 dan AntaraNews.com, PBNU: Upaya deradikalisasi agama belum serius, 5 April 2011 dikutip dari http://www.antaranews.com/berita/1302021092/pbnu-upaya-deradikalisasi-agama-belum-serius diakses pada 23 Mei 2011.

Tim Penyusun Kamus Pusat Bahasa, Kamus Bahasa Indonesia (Jakarta: Pusat Bahasa, 2008), hal. 1203.

6 Nurul Aini (2009), "Pesantren, Organisasi Modern Islam di Masa Penjajahan", dalam Darussalam Jurnal Ilmiah Islam dan Sosial (Martapura: Sekolah Tinggi Agama Islam Darussalam), Vol. 8, No. 1, 2009, hal. 47-64. 
yang dirangkai dengan awalan pe-dan akhiran -an. Santri sendiri berasal dari bahasa Sansekerta, shastri, yaitu orang-orang yang tahu buku-buku suci agama Hindu atau seorang sarjana ahli kitab suci agama Hindu. ${ }^{8}$ Pondok pesantren secara bahasa dengan demikian merupakan perpaduan dari dari dua budaya yang berlainan namun mengakar dalam sejarah Nusantara.

Pondok pesantren dapat disebut sebagai salah satu model pendidikan Islam yang khas Indonesia. Pesantren dengan berbagai variansnya dalam sejarah Indonesia dapat ditelusuri keberadaannya sampai Abad ke-13 M sebagai lembaga pendidikan yang berkembang subur di pedesaan dan daerah terpencil. ${ }^{9}$ Perkembangan selanjutnya menunjukkan pondok pesantren tumbuh sebagai bagian dari dakwah Islam di Pulau Jawa oleh para wali yang biasa disebut sebagai Walisongo. Peranan Walisongo dan pondok pesantren ini makin diperkuat dengan keberpihakan penguasa kerajaan Islam, seperti Sultan Agung di Kerajaan Mataram Islam. ${ }^{10}$

Terkait asal-muasal terbentuknya lembaga pendidikan Islam ini pun masih menjadi objek perdebatan dan kajian yang terus berkembang. Perdebatan atau setidaknya perbedaan pandangan terjadi antara mereka yang melihat bahwa pondok pesantren merupakan produk asli Indonesia, ${ }^{11}$ mereka yang melihat pondok pesantren sebagai derivasi model pendidikan Hindu di India, ${ }^{12}$ maupun yang berpendapat bahwa praktek keislaman di Baghdad saat berada dalam puncak keemasan Islam merupakan inspirasi bagi pembentukan lembaga pendidikan Islam di Indonesia ini. ${ }^{13}$ Apapun pendapat yang dikemukakan, secara umum pondok pesantren diakui sebagai lembaga yang menjaga tugas mulia dalam penyebarluasan ajaran Islam di Nusantara.

7 Tim Penyusun Kamus Pusat Bahasa, Kamus Bahasa Indonesia, hal. 1170.

8 Zainal Abidin, "Pesantren dan Transformasi Sosial: Memotret Peran Pesantren dalam Pembangunan Masyarakat Madani”, dalam Media Nusantara, No. 3, (Bandung: LPPM Universitas Islam Nusantara, 2008), hal. 95-108.

9 Murdan, "Pondok Pesantren dalam Lintasan Sejarah" dalam Ittihad Jurnal Ilmiah Keagamaan, Pendidikan dan Kemasyarakatan, Vol. 2 No.1 April 2004 (Banjarmasin: Kopertais Wilayah XI Kalimantan, 2004), hal. 33-45.

10 Ibid.

11 Said Aqil Husein Al-Munawar, Aktualisai Nilai-nilai Qur'ani dalam Sistem Pendidikan Islam (Jakarta: Ciputat Press, 2005), hal. 205, dikutip dalam Zainal Abidin (2008), "Pesantren dan Transformasi Sosial...", hal. 95-108.

12 Nurcholish Madjid, Bilik-bilik Pesantren: Sebuah Potret Perjalanan (Jakarta: Paramadina, 1997), hal. 3 dan Karel A. Steenbrink, Pesantren, Madrasah, Sekolah: Pendidikan Islam dan Kurun Modern (Jakarta: LP3ES, 1983), hal. 20, dikutip dalam Zainal Abidin, "Pesantren dan Transformasi Sosial...", hal. 95-108.

13 Mahmud Yunus, "Sejarah Pendidikan Islam di Indonesia", (Jakarta: Hidakarya Agung, 1993), hal. 31, dikutip dalam Zainal Abidin, "Pesantren dan Transformasi Sosial...", hal. 95-108. 
Peranan pondok pesantren dalam pendidikan nasional makin terasa di saat penjajahan Belanda mencengkeram tanah air. Pondok pesantren berkembang menjadi lembaga pendidikan alternatif bagi masyarakat luas yang bukan priyayi untuk menempuh pendidikan, mengingat terbatasnya ruang bagi mereka di pendidikan formal yang dilaksanakan penjajah. ${ }^{14}$ Peranan pondok pesantren dalam perkembangan nasional juga tidak dapat dinafikan. Pendidikan yang diberikan lembaga pendidikan Islam ini telah melahirkan sejumlah tokoh nasional yang ikut memperjuangkan dan sekaligus mengisi kemerdekaan. Tokoh-tokoh nasional yang lahir dari rahim pendidikan pondok pesantren dan memberikan dampak besar bagi perjuangan kemerdekaan antara lain H.O.S. Cokroaminoto, K.H. Mas Mansur, K.H. Hasyim Asy'ari, K.H. Ahmad Dahlan, Ki Bagus Hadikusumo, K.H. A. Kahar Muzakkir, dan lain-lain. ${ }^{15}$

Sementara di masa mempertahankan dan mengisi kemerdekaan, tokoh-tokoh alumni pondok pesantren juga berperan penting bagi bangsa seperti tercermin dalam diri Moh. Rosyidi, Moh. Natsir, K.H. A. Wahid Hasyim, K.H. Muslih Purwokerto, K.H. Imam Zarkasy, K.H. Idham Khalid, dan lain-lain. ${ }^{16}$ Peranan alumni pondok pesantren yang dipaparkan sebelumnya secara umum memang berdimensi politik, sebagai salah satu peran yang memang cukup kuat melekat pada lembaga pendidikan Islam ini. Peranan politik ini kemudian mengkulminasi pada capaian K.H. Abdurrahman Wahid sebagai Presiden RI sebagai mandataris MPR pertama yang dihasilkan melalui Pemilu di masa Reformasi. Bahkan setelah K.H. Abdurrahman Wahid diturunkan dari jabatannya dan digantikan Megawati Soekarnoputri, peran alumni pondok pesantren dalam kepemimpinan nasional masih nampak dengan hadirnya Hamzah Haz sebagai wakil presiden. ${ }^{17}$

Secara kelembagaan, pondok pesantren sejak tahun 1970-an mengalami perkembangan yang signifikan. Data Departemen Agama RI menunjukkan bahwa pada 1977 terdapat 4.195 pondok pesantren di Indonesia dengan 677.304 orang santri. Angka ini kemudian meningkat menjadi 6.239 pondok pesantren dengan 1.084 .801 orang santri pada tahun 1985. Jumlah ini terus meningkat menjadi 9.388

14 Nurul Aini (2009), “Pesantren, Organisasi Modern...”, hal. 47-64.

15 Zainal Abidin (2008), "Pesantren dan Transformasi Sosial...", hal. 95-108.

16 Ibid.

17 Abdul Munir Mulkhan (2002), “Dinamika Politik Santri Pasca Reformas»", dalam Tarjih Jurnal Tarjih dan Pengembangan Pemikiran Islam (Yogyakarta: LPPI Universitas Muhammadiyah Yogyakarta dan Majelis Tarjih dan Pengembangan Pemikiran Islam, Pimpinan Pusat Muhammadiyah), Edisi ke-3 Januari 2002, hal. 29-37. 
pondok pesantren dengan 1.770 .768 orang santri pada tahun 1997. Tahun 2001, perkembangan juga terus terjadi dengan jumlah pondok pesantren mencapai 11.312 buah dengan jumlah santri mencapai 2.737 .805 orang. ${ }^{18}$

Perkembangan ini masih terus berlangsung hingga saat ini. Data Kementrian Agama RI menunjukkan bahwa sampai tahun 2008 terdapat 21.521 pondok pesantren yang menyelenggarakan pendidikan di Indonesia. Pondok pesantren ini terdiri dari pondok pesantren Salafiyah (37,18\%), Ashriyah (18,03\%), dan Kombinasi (44,79\%). Data selengkapnya terkait jumlah pondok pesantren menurut jenis penyelenggaraannya tahun akademik 2008 disajikan dalam tabel berikut. Data dari lima provinsi di pulau Jawa dan DKI Jakarta sengaja dimunculkan dalam tabel tersebut untuk menunjukkan besarnya dominasi pondok pesantren di wilayah tersebut. Pulau Jawa menyumbang lebih dari 16 ribu dari total 21 ribu pondok pesantren di Indonesia, atau lebih dari $77 \%$. Hal ini menandakan bahwa kepercayaan masyarakat pada pendidikan pesantren di Pulau Jawa masih terpelihara dengan baik.

\section{Tabel 1.}

Pondok Pesantren Menurut Jenis Penyelenggaraannya

Tahun Akademik 2008

\begin{tabular}{|r|l|r|r|r|r|}
\hline \multirow{2}{*}{ No } & \multirow{2}{*}{ Provinsi } & \multicolumn{4}{|c|}{ Pondok Pesantren } \\
\cline { 3 - 6 } & & Salafiyah & Ashriyah & Kombinasi & $\begin{array}{c}\text { Jumlat } \\
\text { (Total) }\end{array}$ \\
\hline 1 & DKI Jakarta & 21 & 19 & 47 & 87 \\
\hline 2 & Jawa Barat & 2.375 & 652 & 3.178 & 6.205 \\
\hline 3 & Jawa Tengult & 1.725 & 484 & 1.224 & 3.433 \\
\hline 4 & DI Yogyakarta & 116 & 41 & 119 & 276 \\
\hline 5 & Jawa Timur & 779 & 1.119 & 2.291 & 4.189 \\
\hline 6 & Banten & 1.659 & 338 & 517 & 2.514 \\
\hline 7 & Indonesia (Jumlah) & 8.001 & 3.881 & 9.639 & 21.521 \\
\hline 8 & Indonesia (Persentizse) & $37,18 \%$ & $18,03 \%$ & $44,79 \%$ & $100 \%$ \\
\hline
\end{tabular}

Sumber : EMIS pada Direktorat Jenderal Pendidikan Islam Tabel 59, dikutip dari http:// www.kemenag.go.id/file/dokumen/Data0859.pdf diakses 27 Juni 2011.

18 M. Sulthon Mashud dan Moh. Khusnurdilo, "Manajemen Pondok Pesantren", (Jakarta: Diva Pustaka, 2003), hal. 4, dikutip dari Amir Mu'allim, "Isu Terorisme dan Stigmatisasi terhadap Pondok Pesantren (Meluruskan Kesalahpahaman terhadap Pondok Pesantren)”, dalam Millah Jurnal Studi Agama, Vol. VI, No. 1, Agustus 2006, (Yogyakarta: Program Pascasarjana Magister Studi Islam Universitas Islam Indonesia), hal. 47-60. 
Sementara itu, dari sisi jumlah santri yang ada di pendidikan pondok pesantren sampai 2008, disajikan dalam tabel berikut. Data dari Kementrian Agama RI ini menunjukkan jumlah santri pada pondok pesantren menurut tempat tinggal dan jenis kelamin. Pada tahun 2008, tedapat 3.818.469 santri di seluruh Indonesia. Data dari lima provinsi di pulau Jawa dan DKI Jakarta kembali dimunculkan dalam tabel tersebut untuk menunjukkan besarnya komposisi santri yang menempuh pendidikan pondok pesantren di wilayah tersebut. Wilayah ini mencatat jumlah santri sebanyak 2.710 .847 orang atau mencapai lebih dari $70 \%$ jumlah santri secara nasional.

\section{Tabel 2}

Santri pada Pondok Pesantren Menurut Tempat Tinggal dan Jenis Kelamin Tahun 2008

\begin{tabular}{|c|c|c|c|c|c|c|}
\hline \multirow{2}{*}{ No } & \multirow{2}{*}{ Provinsi } & \multirow{2}{*}{$\frac{\text { Sarniri }}{\text { Jumbah }}$} & \multicolumn{2}{|c|}{ Jenis Kelarmin } & \multicolumn{2}{|c|}{$\begin{array}{c}\text { Keteranginn Tempat } \\
\text { Tiluggal }\end{array}$} \\
\hline & & & Prial & Wanita & Mukim & $\begin{array}{l}\text { Tidak } \\
\text { Mukim }\end{array}$ \\
\hline I & DKJ Jakarata & 21.481 & 11.645 & 9.836 & 7.315 & 14.166 \\
\hline 2 & lawa Barilt & 844.241 & 491.858 & 352.383 & 458.922 & 385,319 \\
\hline 3 & lawa Tengatı & 494.700 & 263.071 & 231.629 & 304.826 & 189.874 \\
\hline 4 & D] Yogyakarta & 34.755 & 18.983 & 15.772 & 29,315 & 5.44 \\
\hline 5 & Jawa Thmur & 1.045 .978 & 546.946 & 498.982 & 597.271 & 448.6 .57 \\
\hline 6 & Baпten & 269.742 & 145.740 & 124,0012 & 248.499 & 21.243 \\
\hline 7 & ladonesia (Jumlah) & 3.818 .469 & 2.063 .954 & 1.754 .515 & 2.224 .561 & 1.593 .908 \\
\hline 8 & Indonesia (Persentase) & $100 \%$ & $54,05 \%$ & $45,95 \%$ & $58,26 \%$ & $41,740 \%$ \\
\hline
\end{tabular}

Sumber : EMIS pada Direktorat Jenderal Pendidikan Islam Tabel 60, dikutip dari http:// www.kemenag.go.id/file/dokumen/Data0860.pdf diakses 27 Juni 2011.

Adapun jumlah pengajar yang mengabdikan diri pada pendidikan di pondok pesantren secara nasional menurut data Kementrian Agama RI pada tahun 2008 mencapai 281.591 orang. Data lengkap pengajar pada pondok pesantren menurut jenis kelamin dan status kepegawaian untuk tahun 2008 disajikan dalam tabel berikut. Data pengajar pada lima provinsi di pulau Jawa dan DKI Jakarta menunjukkan besarnya komposisi dengan mencatat sebanyak 2.710 .847 orang pengajar atau mencapai hampir 70\% jumlah pengajar secara nasional. 


\section{Tabel 3}

\section{Pengajar pada Pondok PesantrenMenurut Jenis Kelamin dan Status Kepegawaian Tahun 2008}

\begin{tabular}{|c|c|c|c|c|c|c|c|c|c|}
\hline \multirow{2}{*}{ No } & \multirow{2}{*}{ I'novins } & \multirow{2}{*}{$\frac{\text { Pengiti표 }}{\text { [unclinl] }}$} & \multicolumn{3}{|c|}{ Jubatan } & \multicolumn{2}{|c|}{ Jenis Kel_mmin } & \multicolumn{2}{|c|}{ 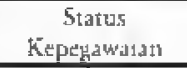 } \\
\hline & & & IKyai & Ustadz & Luinnya & Pria & Wanita & PNS & $\begin{array}{l}\text { Nan } \\
\text { PNS }\end{array}$ \\
\hline 1 & 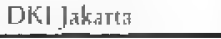 & 2.1463 & 250 & 1.63 & 183 & 1.273 & 790 & 57 & 2.] [1] \\
\hline 2 & Jаw: Eal'al & 45.724 & 12.549 & 30,318 & 2.857 & 28.973 & ! $6.75 \mathrm{I}$ & 4.26 & 41.464 \\
\hline 3 & Jaw Tergati & 41.803 & 9.505 & 29.126 & 3.172 & 27.460 & 14.343 & $2.4 I$ & 39.393 \\
\hline 4 & DI Yogyukudu & 3.451 & 477 & 2.603 & 371 & 2.262 & 1.189 & 97 & 3.354 \\
\hline 5 & 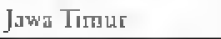 & 93282 & 13.975 & $73.64 !$ & 6.244 & 59.925 & 33.357 & 2.232 & 91.05 \\
\hline 吕 & Banten & 9,847 & 3.238 & 0,274 & 335 & 7.017 & 2.830 & 107 & 9.74 \\
\hline 7 & Indones] (Tulah) & 281,541 & 48,479 & 213.951 & 18.6女1 & 181.133 & 100.458 & 13.278 & 268.313 \\
\hline 8 & $\begin{array}{l}\text { Jadoriesta } \\
\text { (Persentage) }\end{array}$ & 10,06040 & $17,3990 \mathrm{~h}$ & 75,9804 & $6,630 \%$ & 64,32 With & $35,68 \%$ & $4,720 \mathrm{~h}$ & $95,28 \%$ \\
\hline
\end{tabular}

Sumber : EMIS pada Direktorat Jenderal Pendidikan Islam Tabel 61, dikutip dari http:// www.kemenag.go.id/file/dokumen/Data0861.pdf diakses 27 Juni 2011.

Komposisi kepegawaian para pengajar yang sebagian besar adalah Non PNS (95,28\% dari total pengajar) secara umum menunjukkan posisi pondok pesantren sebagai lembaga pendidikan yang independen sekaligus menunjukkan personalitas pengajar yang teguh memegang keikhlasan dalam menjalankan tugasnya. Pondok pesantren yang independen tentu saja sangat penting peranannya dalam menjaga posisi dengan kekuatan politik yang ada. Sementara itu, keikhlasan sebagai salah satu akhlak pengajar menjadi bagian penting dari peran pondok pesantren dalam menjaga moral bangsa. Peran pondok pesantren sebagai garda depan menjaga moralitas memang sudah sejak lama menjadi bagian penting dalam pendidikan karakter bangsa.

Komposisi ini juga menunjukkan peran kyai yang secara umum masih sangat kental dalam pondok pesantren (17,39\% dari total pengajar). Sebagai tokoh karismatik, kyai tidak saja dihormati oleh para santri, tetapi juga oleh masyarakat sekitar pondok pesantren sehingga tidak mengherankan jika sejak masa penjajahan, peran agama dan peran politik (termasuk peran sosial) selalu melingkupi kyai. ${ }^{19}$

19 Amir Fadhilah, "Budaya Politik Kyai Pedesaan: Studi Kasus Kyai Pesantren di Kabupaten Pekalong an", dalam Alqalam Jurnal Ilmiah Bidang Keagamaan dan Kemasyarakatan Vol. 24, No. 1, Januari-April 2007, (Banten: PPPM Institut Agama Islam Negeri Sultan Maulana Hasanuddin), hal. 37-54. 


\section{Pondok Pesantren dan Deradikalisasi Islam di Indonesia}

Adanya sejumlah kyai yang berafiliasi secara langsung dengan pemerintah sebagai abdi negara atau kyai yang menjadi PNS, di satu sisi merupakan kelebihan mengingat hal ini akan mengoptimalkan peran yang selama ini telah dilaksanakan. Posisi kyai PNS yang strategis ini tetap harus diarahkan untuk menjaga kualitas pendidikan pondok pesantren sekaligus integritas kyai sendiri. ${ }^{20}$

\section{Radikalisasi Agama dalam Konteks Indonesia}

Secara umum gerakan radikal Islam sebagai bagian dari gerakan Islamisme global dapat ditelusuri akar keberadaannya dari pemikiran pendiri Ikhwanul Muslimin, Hasan Al-Bana (1906-1949), di Mesir dan pendiri Partai Jamaat-I Islami, Abul A'la Al-Maududi (1903-1978), di India. ${ }^{21}$ Ideologi Islamis ini makin mengental dibawah penajaman pemikiran yang digagas Sayyid Quthb melalui beberapa karyanya. Tawarannya tentang jihad sebagai upaya menegakkan berlakunya Hakimiyyat Allah (tegaknya Hukum Allah sebagai satu-satunya pengatur kehidupan) menjadi basis dari hampir semua ideologi jihadis di dunia. ${ }^{22}$

Ideologi ini kemudian melahirkan sejumlah gerakan sempalan yang beraliran keras (semisal Hizbut Tahrir, Jihad Islam, Jamaah Islamiyyah, Jamaah al-Takfir, dsb) dan berkembang secara internasional termasuk ke sejumlah negara seperti Indonesia. ${ }^{23}$ Dalam konteks kesejarahan Indonesia, gerakan radikal Islam biasa dikaitkan dengan DI/TII pimpinan R.M. Kartosuwiryo di Jawa Barat maupun Kahar Muzakkar di Sulawesi Selatan. Benih-benih ideologi ini bersama dengan euforia

20 Fathurrahman (2008), "Kyai Pesantren: Kyai PNS; Wajah Pendidikan Islam Tradisional Bima", dalam KreatifJurnal Studi Pendidikan, Vol. V, No. 1, Januari 2008, (Bima: Lembaga Penelitian Pengabdian Masyarakat Sekolah Tinggi Agama Islam Muhammadiyah Bima), hal. 75-92.

21 Oliver Roy, L'ichec de I'lslam politique. Carol Volk (terj.), The Failure of Political Islam (Cambridge: Harvard University Press, 1994), hal. 1-2.

22 Bassam Tibi, "Religious Extremism or Religionization of Politics? The Ideological Foundations of Political Islam", dalam Hillel Frisch dan Efraim Inbar (eds.), Radical Islam and International Security: Challenges and Responses (New York: Routledge, 2008), hal. 13; Ahmad Asroni, "Radikalisme Islam di Indonesia: Tawaran Solusi untuk Mengatasinya" dalam Religi Jurnal Studi Agama-agama, Vol. VII, No. 1, Januari 2008, (Yogyakarta: Fakultas Ushuluddin Universitas Islam Negeri Sunan Kalijaga), hal. 15-34, dan Noorhaidi Hasan, "Ideologi, Identitas, dan Ekonomi Politik Kekerasan: Mencari Model Solusi Mengatasi Ancaman Radikalisme dan Terorisme di Indonesia", Makalah dalam Simposium Nasional: Memutus Rantai Radikalisme dan Terorisme, Jakarta, Le Meredian Hotel, 27-28 Juli 2010.

23 Haedar Nashir, "Gerakan Islam Syari'at: Reproduksi Salafiyah Ideologis di Indonesia", dalam Maarif Arus Pemikiran Islam dan Sosial, Vol. 1, No. 2, November 2006, (Jakarta: Maarif Institute for Culture and Humanity), hal. 25-120. 
kebebasan di Era Reformasi yang membawa dengan mudah aneka pemikiran baru, termasuk ideologi radikal Timur Tengah, melahirkan sejumlah gerakan Islam di tanah air, baik yang masih mengambil nama asli gerakannya, maupun yang sebatas ideologinya. Gerakan yang ada pun beragam sifat dan jangkauannya, baik level lokal maupun nasional. ${ }^{24}$

Perkembangan gerakan Islam transnasional ini kemudian bersama-sama dengan beragam faktor lokal Indonesia membangkitkan sejumlah gerakan radikalisme dan mengarah terorisme yang belakangan ini terjadi. Kepala Badan Nasional Penanggulangan Terorisme (BNPT), Ansyaad Mbai, melihat sejumlah alasan munculnya gerakan radikalisasi Islam di Indonesia, yaitu kemiskinan, korupsi, globalisasi, dan sejarah. ${ }^{25}$ Pandangan serupa disampaikan Muhammad Tholhah Hasan, yang menilai munculnya gerakan radikalisme di Indonesia terutama setelah Reformasi disebabkan variabel ajaran dan pemahaman, peranan media internet (IT), kondisi sosial domestik, dan konstalasi politik internasional. ${ }^{26}$

Kemiskinan merupakan lahan subur bagi berseminya benih-benih radikalisme paham keagamaan yang berujung pada tindakan teror mengingat masyarakat dalam kelompok ini sangat rentan terhadap bujukan dan rayuan. Kehidupan yang sulit telah dihadapi banyak masyarakat Indonesia baik akibat kegagalan negara dalam melaksanakan misi kesejahteraan maupun tekanan ekonomi kapitalis. Akibatnya, ajakan untuk mencapai kehidupan yang lebih baik, terutama di akhirat, dengan jalan jihad menemukan lahan subur yang sewaktu-waktu siap menghadirkan ancaman. Kemiskinan memang menjadi fenomena menyedihkan dalam kehidupan bangsa saat ini. Sejak Era Reformasi hingga sekarang, puluhan juta rakyat hidup dalam kemiskinan. Angka resmi yang ada menunjukkan bahwa sampai Maret 2011 terdapat 30,02 juta penduduk atau (12,49\%) hidup di bawah garis kemiskinan. ${ }^{27}$ Selama fenomena kemiskinan masih terus muncul, maka upaya menghilangkan radikalisme akan sangat sulit dilakukan. ${ }^{28}$

24 Ahmad Asroni, "Radikalisme Islam..., hal. 15-34.

25 Christopher S. Bond dan Lewis M. Simons, The Next Front: Southeast Asia and the Road to Global Peace with Islam (New Jersey: John Wiley \& Sons, Inc., 2009), hal. 94-5.

26 Muhammad Tholhah Hasan, "Mozaik Islam Indonesia-Nusantara: Dialektika Keislaman dan Keindonesiaan", makalah disampaikan dalam Annual Conference on Islamic Studies 2010, Banjarmasin 1-4 November 2010.

27 Badan Pusat Statistik, Berita Resmi Statistik, No. 45/07/Th. XIV, 1 Juli 2011.

28 Ahmad Syafii Maarif, "Radikalisme, Ketidakadilan, dan Rapuhnya Ketahanan Bangsa", dalam Maarif Arus Pemikiran Islam dan Sosial, Vol. 5, No. 2, Desember 2010, (Jakarta: Maarif Institute for Culture and Humanity), hal. 147-158. 
Pada saat yang sama, korupsi sebagai bentuk penyimpangan keuangan negara oleh oknum penguasa juga terus menjadi fenomena dalam kehidupan bernegara. Indeks Persepsi Korupsi atau Corruption Perceptions Index (CPI) yang dikeluarkan oleh Transparency International sejak 1995 selalu menempatkan Indonesia sebagai salah satu negara yang dipersepsikan sangat korup, tidak jauh dari negara berperingkat terendah. Data tahun 2010, menunjukkan bahwa Indonesia berada pada posisi 110 (dari 170 negara yang disurvei) dengan nilai 2,8 atau setara dengan Benin, Bolivia, Gabon, Kosovo, dan Kepulauan Solomon. Posisi ini menjadikan Indonesia kalah kompetitif dibandingkan negara tetangga seperti Thailand (di peringkat 78), Malaysia (56), Brunei Darussalam (38), Singapore (1). ${ }^{29}$

Selain ikut memiskinkan masyarakatnya, korupsi secara langsung juga berdampak pada makin rendahnya keyakinan akan kapasitas negara dalam menjalankan tugasnya sehingga bujukan halus untuk mendirikan negara Islam dengan berbagai kelebihan dan keutamaannya menjadi lebih mudah menemukan massa pendukung. Pada saat yang sama, selain kegagalan menciptakan kesejahteraan dalam kehidupan rakyat, pemerintah juga mengalami kegagalan dalam menjaga kehidupan masyarakat yang majemuk. Akibatnya, sentimen keagamaan, kesukuan, dan sentimen lainnya mudah sekali memantik munculnya aksi kekerasan dalam masyarakat. ${ }^{30}$

\section{Deradikalisasi Agama Melalui Pondok Pesantren}

Sesuai dengan kajian sebelumnya, pondok pesantren di Indonesia secara umum tidak dapat diasosiasikan dengan gerakan ataupun pemikiran Islam radikal sebagai bentuk baru dari gerakan transnasional. Hal ini mengingat karakteristik pondok pesantren di Indonesia yang secara umum memang berbeda dengan lembaga pendidikan Islam sejenis di negara lain. Selain itu, fakta bahwa Islam datang ke tanah air dengan penuh perdamaian, karena disampaikan melalui dakwah bil hâl para pedagang muslim dan bukan melalui pedang atau pasukan perang, turut mewarnai pemahaman keislaman yang dikembangkan di pondok pesantren. Ajaran

29 Transparency International, Corruption Perceptions Index 2010 (Berlin: Transparency International, 2010), hal. 2-3.

30 Zakiyuddin Baidhawy (2010), "Budaya Kekerasan dan Manajemen Masyarakat Multikultural”, dalam Maarif Arus Pemikiran Islam dan Sosial, Vol. 5, No. 2, Desember 2010, (Jakarta: Maarif Institute for Culture and Humanity), hal. 135-146. 
jihad sebagaimana dipahami kalangan pondok pesantren pun, berbeda jauh dengan pandangan umum dalam gerakan Islam radikal secara umum. ${ }^{31}$

Deradikalisasi melalui pondok pesantren, dengan memperhatikan temuan di atas, dengan demikian harus dilaksanakan dalam kerangka penguatan institusi untuk mengurangi celah-celah sosial, ekonomi, dan politik yang memungkinkan tumbuhnya paham radikalisme agama dan menjurus terorisme. Peran aktif pihak terkait, terutama pemerintah, dapat diarahkan untuk menguatkan peranan pondok pesantren dalam mengatasi permasalahan ekonomi, sosial, dan lainnya yang menjadi lahan persemaian pemikiran radikal tersebut. Hal ini sekaligus menunjukkan bahwa deradikalisasi yang diarahkan pada pendekatan kontrol kurikulum pondok pesantren kurang relevan dilakukan, baik karena jumlah pondok pesantren yang ada sedemikian banyak maupun karena karakteristik masing-masing pesantren yang sangat mengedepankan sosok kyai sebagai panutan.

Pilihan melakukan deradikalisasi melalui penguatan institusi sebenarnya juga merupakan bagian dari tugas pemerintah di bidang pendidikan sebagai bentuk pengakuan akan eksistensi dan peran strategis yang selama ini telah diberikan pondok pesantren. Pondok pesantren selama ini telah memberikan bukti nyata akan komitmen kepada bangsa dan negara meskipun imbal balik yang setimpal belum sepenuhnya diberikan pemerintah. Pondok pesantren, terutama yang berada dalam naungan Nahdhatul Ulama secara khusus, telah membuktikan perannya dalam perjuangan kemerdekaan melalui perjuangan fisik maupun pernyataan anti penjajahan sebagaimana tergambar dalam Resolusi Jihad yang dikeluarkan dalam Muktamar NU di Surabaya, 21 dan 22 Oktober 1945. ${ }^{32}$

Pondok pesantren juga telah menunjukkan perannya dalam menjaga stabilitas politik melalui pengakuan dan penerimaan Pancasila sebagai asas tunggal dalam organisasi sebagaimana diwakili, setidaknya oleh pondok pesantren dibawah afiliasi, Nahdhatul Ulama. Melalui keputusan Muktamar NU ke-27 di Pondok Pesantren Salafiyah Syafi'iyyah Sukorejo Situbondo, 8-12 Desember 1984, Nahdhatul Ulama

31 Terkait bagaimana pondok pesantren memandang jihad, lengkap dengan etika perang yang berlaku, lihat Amir Mu'allim, "Isu Terorisme dan Stigmatisasi..., hal. 47-60.

32 Resolusi Jihad NU yang terkenal tersebut kemudian ditegaskan kembali dengan fatwa K.H. Hasyim Asy'ari yang dimuat di Kedaulatan Rakjat, 20 November 1945 yang antara lain menegaskan bahwa pertama memerangi orang kafir dalam hal ini Netherlands Indies Civil Administrations(NICA) yang ingin menancapkan kembali kekuasaannya di Indonesia adalah fardhu 'ain, kedua siapa yang meninggal dalam perang melawan NICA dihukumi syahid, dan ketiga siapa yang memecah persatuan saat ini hendaknya dihukum bunuh. Selengkapnya lihat Nico J.G. Kaptein (2000), "Acceptance, Approval and Aggression: Some Fatwas Concerning the Colonial Administration in the Dutch East Indies"dalam Al-Jâmi'ah, Vol. 38, No. 2, 2000, 297-308. 
telah menyatakan persetujuannya untuk menerima Pancasila sebagai asas tunggal bahkan sebelum Undang-undang tentang organisasi massa diumumkan pemerintah..$^{33}$ Namun demikian, dengan kontribusi besar tersebut, pondok pesantren tidak serta merta mendapat perhatian serius dari pemerintah di masa lalu, terutama di bidang pengembangan ekonomi.

Kini dengan semakin pentingnya deradikalisasi pemikiran Islam melalui pendidikan, sudah sewajarnya bila komitmen kebangsaan yang telah ditunjukkan pondok pesantren dibayar lunas oleh pemerintah dengan perhatian yang memadai. Hal ini dapat dilakukan dengan merangkul pondok pesantren dalam program pemberdayaan masyarakat yang umum digalakkan pemerintah saat ini. Terdapat dua sisi sekaligus yang dapat dicapai melalui langkah ini, yaitu mengurangi dampak sosial, ekonomi, dan politik melalui jalur yang lebih kompromis karena melibatkan institusi pendidikan Islam ${ }^{34}$ dan juga mengurangi bias persepsi terhadap birokrasi yang secara umum dianggap koruptif dalam pelaksanaan program pemerintah.

Sejumlah pondok pesantren sudah lama terlibat dalam proses pembangunan berbasis masyarakat sebagai bagian penting dalam membentuk masyarakat madani ini sehingga pelaksanaannya tentulah tidak begitu menyulitkan. ${ }^{35}$ Bagian terberat tentu saja ada pada kemauan politik pemerintah dalam menjalankan program yang terfokus pada umat Islam, tanpa ketakutan dan trauma masa lalu atas hubungan Islam dan politik. Selain hambatan birokrasi yang lazim ditemui, ${ }^{36}$ pilihan kebijakan

33 Faisal Ismail, Islam, Politics and Ideology in Indonesia: A Study of the Proccess of Muslim Acceptance of the Pancasila. Imron Rosyidi (terj.) Ideologi, Hegemoni, dan Otoritas Agama: Wacana Ketegangan Kreatif antara Islam dan Pancasila (Yogyakarta: Tiara Wacana Yogya, 1999), hal. 235.

34 Sejumlah program telah dilaksankan pemerintah dalam rangka mengatasi masalah tersebut, namun kesemuanya dengan nama dan sasaran rakyat Indonesia secara umum. Program yang mengarah secara khusus kepada masyarakat muslim tentu perlu dimunculkan sebagai bukti konsistensi dan komitmen pemerintah.

35 M.A. Fattah Santoso, "Pesantren dan Pengembangan Masyarakat Madani”, dalam Profetika Jurnal Studi Islam, Vol. 1, No. 2, Juli 1999, (Surakarta: Program Magister Studi Islam Universitas Muhammadiyah Surakarta), hal. 177-191, Scott Allen Buresh, "Pesantren-Based Development: Islam, Education, and Economic Development in Indonesia", Desertasi disampaikan pada Departemen Antropologi University of Virginia (Miami: ProQuest Information and Learning, 2002) dan Akhtim Wahyuni, "Peran Sosial Pesantren dalam Pemberdayaan Masyarakat", dalam Kreatif Jurnal Studi Pendidikan, Vol. VI, No. 1, Januari 2009, (Bima: Lembaga Penelitian Pengabdian Masyarakat Sekolah Tinggi Agama Islam Muhammadiyah Bima), hal. 27-34.

${ }^{36}$ Hambatan birokasi juga menjadi salah satu masalah dalam soft approach sebagai pelengkap dan penyempurna hard approach yang sudah dilakukan dalam mengatasi masalah terorisme di Indonesia. Lihat Muhammad Tito Karnavian, "The "Soft Approach" Strategy in Coping with Islamist Terrorism in Indonesia”. Makalah dalam Simposium Nasional: Memutus Rantai Radikalisme dan Terorisme, Jakarta, Le Meredian Hotel, 27-28 Juli 2010. 
ini juga memang tidak berdampak dalam waktu dekat sehingga terkesan membutuhkan lebih banyak waktu dan tenaga. Pilihan menggunakan pendekatan kepada pondok pesantren ini juga lebih strategis dilakukan mengingat dampaknya tidak hanya dapat dirasakan kalangan pondok pesantren saja tetapi juga meluas pada masyarakat sekitar.

\section{E. Penutup}

Pembahasan yang telah dikemukakan di atas menunjukkan bahwa pondok pesantren di Indonesia berkembang dalam kerangka yang relatif khas dan memiliki watak yang berbeda dengan pendidikan sejenis di negara lain mengingat sifat damai yang dirasakan saat Islam masuk ke tanah air. Hal ini membawa implikasi berupa watak keislaman yang damai di sebagian besar pondok pesantren yang ada termasuk kontribusi yang diberikan bagi bangsa dan negara. Bahwa kemudian terjadi radikalisasi pemahaman pada pondok pesantren tertentu yang berdampak pada aksi terorisme di Indonesia selayaknya diletakkan dalam konteks perkembangan gerakan Islam transnasional akibat berbagai perkembangan dunia yang ada. Pembahasan singkat ini juga menekankan pentingnya penguatan peran pemerintah dalam upaya deradikalisasi Islam melalui pondok pesantren dengan penguatan institusi lembaga pendidikan Islam tersebut dalam bentuk dukungan program pemberdayaan masyarakat untuk memutus rantai gerakan. Pendekatan ini dinilai lebih efektif dalam jangka panjang karena akan meminimalisir ruang bagi persemaian pemikiran radikal sekaligus penguatan peran sosial pondok pesantren di masyarakat.

\section{DAFTAR PUSTAKA}

Abidin, Zainal. 2008. "Pesantren dan Transformasi Sosial: Memotret Peran Pesantren dalam Pembangunan Masyarakat Madani”, dalam Media Nusantara. Bandung: LPPM Universitas Islam Nusantara. No. 3, 2008, hal. 95-108.

Aini, Nurul. 2009. “Pesantren, Organisasi Modern Islam di Masa Penjajahan”, dalam Darussalam Jurnal Ilmiah Islam dan Sosial. Martapura: Sekolah Tinggi Agama Islam Darussalam. Vol 8, No. 1, 2009, hal. 47-64.

Al-Munawar, Said Aqil Husein. 2005. Aktualisai Nilai-nilai Qur'ani dalam Sistem Pendidikan Islam. Jakarta: Ciputat Press. 
AntaraNews.com, “PBNU: Upaya deradikalisasi agama belum serius”, 5 April 2011 dikutip dari http://www.antaranews.com/berita/1302021092/pbnu-upayaderadikalisasi-agama-belum-serius diakses pada 23 Mei 2011.

Arrahmah Online, "Proyek Deradikalisasi: BNPT "Cuci Otak" Ulama, Ormas Islam, dan Takmir Masjid", 3 Desember 2010 dikutip dari http://arrahmah.com/ read/2010/12/03/10148-proyek-deradikalisasi-bnpt-cuci-otak-ulama-ormasislam-dan-takmir-masiid.html diakses pada 23 Mei 2011.

Asroni, Ahmad. 2008. “Radikalisme Islam di Indonesia: Tawaran Solusi untuk Mengatasinya”, dalam Religi Jurnal Studi Agama-agama. Yogyakarta: Fakultas Ushuluddin Universitas Islam Negeri Sunan Kalijaga. Vol. VII, No. 1, Januari 2008, hal. 15-34.

Badan Pusat Statistik. 2011. Berita Resmi Statistik, No. 45/07/Th. XIV, 1 Juli 2011. Baidhawy, Zakiyuddin. 2010. “Budaya Kekerasan dan Manajemen Masyarakat MultikulturaP', dalam Maarif Arus Pemikiran Islam dan Sosial. Jakarta: Maarif Institute for Culture and Humanity. Vol. 5, No. 2, Desember 2010, hal. 135-146.

Bond, Christopher S. dan Simons, Lewis M. 2009. The Next Front: Southeast Asia and the Road to Global Peace with Islam. New Jersey: John Wiley \& Sons, Inc.

Buresh, Scott Allen. 2002. "Pesantren-Based Development: Islam, Education, and Economic Development in Indonesia”, Desertasi disampaikan pada Departemen Antropologi University of Virginia. Miami: ProQuest Information and Learning.

Fadhilah, Amir. 2007. “Budaya Politik Kyai Pedesaan: Studi Kasus Kyai Pesantren di Kabupaten Pekalongan”, dalam Alqalam Jurnal Ilmiah Bidang Keagamaan dan Kemasyarakatan. Banten: PPPM Institut Agama Islam Negeri Sultan Maulana Hasanuddin. Vol. 24, No. 1, Januari-April 2007, hal. 37-54.

Fathurrahman. 2008. "Kyai Pesantren: Kyai PNS; Wajah Pendidikan Islam Tradisional Bima”, dalam Kreatif Jurnal Studi Pendidikan. Bima: Lembaga Penelitian Pengabdian Masyarakat Sekolah Tinggi Agama Islam Muhammadiyah Bima. Vol. V, No. 1, Januari 2008, hal. 75-92. 
Hasan, Muhammad Tholhah. 2010. “Mozaik Islam Indonesia-Nusantara: Dialektika Keislaman dan Keindonesiaan”, makalah disampaikan dalam Annual Conference on Islamic Studies 2010, Banjarmasin 1-4 November 2010.

Hasan, Noorhaidi. 2010. "Ideologi, Identitas, dan Ekonomi Politik Kekerasan: Mencari Model Solusi Mengatasi Ancaman Radikalisme dan Terorisme di Indonesia”, Makalah dalam Simposium Nasional: Memutus Rantai Radikalisme dan Terorisme, Jakarta, Le Meredian Hotel, 27-28 Juli 2010.

Ismail, Faisal. 1999. Islam, Politics and Ideology in Indonesia: A Study of the Proccess of Muslim Acceptance of the Pancasila. Imron Rosyidi (terj.) Ideologi, Hegemoni, dan Otoritas Agama: Wacana Ketegangan Kreatif antara Islam dan Pancasila. Yogyakarta: Tiara Wacana Yogya.

Kaptein, Nico J.G.. 2000. "Acceptance, Approval and Aggression: Some Fatwas Concerning the Colonial Administration in the Dutch East Indies"dalam Al-Jâmi'ah, Vol. 38, No. 2, 2000, 297-308.

Karnavian, Muhammad Tito. 2010. "The "Soft Approach" Strategy in Coping with Islamist Terrorism in Indonesia”. Makalah dalam Simposium Nasional: Memutus Rantai Radikalisme dan Terorisme, Jakarta, Le Meredian Hotel, 27-28 Juli 2010.

Maarif, Ahmad Syafii. 2010. "Radikalisme, Ketidakadilan, dan Rapuhnya Ketahanan Bangsa”, dalam Maarif Arus Pemikiran Islam dan Sosial. Jakarta: Maarif Institute for Culture and Humanity. Vol. 5, No. 2, Desember 2010, hal. 147-158.

Madjid, Nurcholish. 1997. Bilik-bilik Pesantren: Sebuah Potret Perjalanan. Jakarta: Paramadina.

Majalah Barometer Online, "Acara Deradikalisasi Dibungkus Dengan Wayang”, 4 April 2011 dikutip dari http://barometerpost.com/terorisme/85-acaraderadikalisasi-dibungkus-dengan-wayang.html diakses pada 23 Mei 2011.

Mashud, M. Sulthon dan Khusnurdilo, Moh.. 2003. Manajemen Pondok Pesantren. Jakarta: Diva Pustaka.

Mu'allim, Amir. 2006. “Isu Terorisme dan Stigmatisasi terhadap Pondok Pesantren (Meluruskan Kesalahpahaman terhadap Pondok Pesantren)”, dalam Millah Jurnal Studi Agama. Yogyakarta: Program Pascasarjana Magister Studi Islam Universitas Islam Indonesia. Vol. VI, No. 1, Agustus 2006, hal. 47-60. 
Mulkhan, Abdul Munir. 2002. "Dinamika Politik Santri Pasca Reformasi”, dalam Tarjih Jurnal Tarjih dan Pengembangan Pemikiran Islam. Yogyakarta: LPPI Universitas Muhammadiyah Yogyakarta dan Majelis Tarjih dan Pengembangan Pemikiran Islam, Pimpinan Pusat Muhammadiyah. Edisi ke-3 Januari 2002, hal. 29-37.

Murdan. 2004. "Pondok Pesantren dalam Lintasan Sejarah" dalam Ittihad Jurnal Ilmiah Keagamaan, Pendidikan dan Kemasyarakatan. Banjarmasin: Kopertais Wilayah XI Kalimantan. Vol. 2 No.1 April 2004 hal. 33-45.

Nahdhatul Ulama Online, "PBNU Gelar Simposium Nasional Deradikalisasi Agama", 30 Oktober 2010 dikutip dari http://www.nu.or.id/page/id/dinamic detil/1/ 25292/Warta/PBNU Gelar Simposium Nasional Deradikalisasi Agama.html diakses pada 23 Mei 2011.

Nashir, Haedar. 2006. "Gerakan Islam Syari'at: Reproduksi Salafiyah Ideologis di Indonesia”, dalam Maarif Arus Pemikiran Islam dan Sosial. Jakarta: Maarif Institute for Culture and Humanity. Vol. 1, No. 2, November 2006, hal. 25-120.

Republika Newsroom, "Perlu Deradikalisasi Pemahaman Islam di Ponpes”, Jumat, 6 Februari 2009 dikutip dari http://koran.republika.co.id/berita/29871 diakses pada 23 Mei 2011.

Roy, Oliver. 1994. L'ichec de l'Islam politique. Carol Volk (terj.), The Failure of Political Islam. Cambridge: Harvard University Press.

Situs Online Universitas Gadjah Mada, "Perangi Terorisme Kedepankan Strategi Deradikalisasi”, 1 Maret 2011 dikutip dari http://www.ugm.ac.id// index.php?page=rilis\&artikel=3493 diakses pada $23 \mathrm{Mei} 2011$.

Steenbrink, Karel A. (1983), Pesantren, Madrasah, Sekolah: Pendidikan Islam dan Kurun Modern. Jakarta: LP3ES.

Tibi, Bassam. 2008. "Religious Extremism or Religionization of Politics? The Ideological Foundations of Political Islam", dalam Frisch, Hillel dan Inbar, Efraim (eds.) (2008), Radical Islam and International Security: Challenges and Responses. New York: Routledge.

Tim Penyusun Kamus Pusat Bahasa. 2008. Kamus Bahasa Indonesia. Jakarta: Pusat Bahasa. 
Transparency International, Corruption Perceptions Index 2010. Berlin: Transparency International.

Wahyuni, Akhtim. 2009. "Peran Sosial Pesantren dalam Pemberdayaan Masyarakat", dalam Kreatif Jurnal Studi Pendidikan. Bima: Lembaga Penelitian Pengabdian Masyarakat Sekolah Tinggi Agama Islam Muhammadiyah Bima. Vol. VI, No. 1, Januari 2009, hal. 27-34.

Yunus, Mahmud. 1993, Sejarah Pendidikan Islam di Indonesia. Jakarta: Hidakarya Agung. 